УДК 821.112 .2

ББК $83.3(4)$

\section{А.Г. Барова}

\section{ФУНКЦИОНИРОВАНИЕ ИНТЕРТЕКСТА \\ B POMAHE Э. KAHETTИ «ОСЛЕПЛЕНИЕ"}

Предпринята попытка изучения интертекста и его функций в романе Элиаса Канетти «Ослепление». Показано, что интертекст является одним из приемов создания гротеска и пародии в произведении. Включая в текст различные литературные традиции, писатель выражает свое отношение к сложившейся действительности и рисует картину общества в связи со своим видением мира.

Ключевые слова: интертекст, цитирование, аллюзия, литературная традиция.

DOI 10.18522/1995-0640-2020-2-156-160

Барова Алена Геннадьевна - старший преподаватель кафедры немецкой филологии Елабужского института Казанского федерального университета Тел.: 8-987-219-37-18

E-mail: AGBarova81@mail.ru

(C) Барова А.Г., 2020.
Своеобразие любого художественного произведения обусловливается, прежде всего, особенностью авторского мировосприятия, той общественно-культурной средой, которая его окружает. Элиас Канетти (1905-1994) - писатель с провидческим взглядом, сумевший метко и точно дать характеристику современной ему эпохи, тонко предугадывая все коллизии грядущего, что достигается путем использования в текстах мифологических элементов, аллюзий и реминисценций. Его творчество отличается многожанровостью (пьесы, роман, автобиографический цикл, заметки, эссе, поэтические сборники, теоретический философско-социологический труд «Масса и власть») и представляет собой обширное пространство для исследования.

Роман «Ослепление» (19311932), написанный почти девяносто лет назад, по сей день привлекает внимание многих зарубежных и отечественных литературоведов, предлагая каждый раз новую почву для исследования. Одной из особенностей романа является то, что он вобрал в себя традиции многих духовных культур. Культурное пространство романа составляют выдержки из библейских текстов, китайской философии (Конфуций, Лао-цзы, Мэн-цзы) и мифологии, литературного наследия античности, прослеживаются связи с литературными традициями Кафки, Гоголя, Достоевского - и все это лишь небольшой ряд, имевший влияние при написании романа и нашедший в нем отражение.

Книга повествует о профессоре-синологе, живущем ради науки 
и своих книг. Однажды ему приходит в голову мысль жениться на своей экономке Терезе, чтобы обеспечить своим книгам большую безопасность, как ему казалось. С этого момента его судьба меняется кардинальным образом и в конце он сжигает себя вместе с книгами.

Роман «Ослепление» предстает как «мозаика» сюжетов и мотивов, цитат из других текстов, звучащих из уст действующих фигур и являющихся отличительной особенностью их стиля речи. Цитаты и аллюзии, выполняя в тексте функцию типизации, усиливают особенности образов и явлений. В данном произведении интертекст проявляется как во внутренних монологах фигур романа, так и в их прямой речи, представляя собой «акустическую маску» (термин, введенный Э. Канетти). «Акустическую маску» можно охарактеризовать как речевой портрет отдельного человека, доведенный до того предела, где общепонятный, человеческий язык теряет свои границы и переходит в разряд примитивного языка, схожего с жаргоном, усиливая тем самым непонимание между людьми [Шастина, 2004, с. 73].

Домработница Петера Кина, главного персонажа романа, Тереза Крумбгольц использовала в речи казавшиеся ей необычайно красивыми обороты и фразы, вычитанные из газетных объявлений. Бедность её речи - это отражение убогости её внутреннего мира, отсутствие способности размышлять и сочувствовать. Отличительной чертой главного героя Канетти Питера Кина становится его портрет синолога, живущего в собственном мире, наполненном книгами.

В период создания романа Канетти активно интересуется философией и культурой Китая, открыв для себя в качестве образцового произведения «Беседы Конфуция», являющиеся отражением образа идеального человека, «древнейшего законченного духовного портрета человека» [Канетти, 1990, с. 92]. В «Ослеплении» интертекст определяется, прежде всего, характером фигуры Петера Кина. Его образ связан с многочисленными цитатами из китайской философии и, в первую очередь, его характер, сотканный по образцу Конфуция. Петеру Кину были присущи скрупулезная осторожность и медлительность мысли, размышления, речь, выстроенная в ритме чередования вопроса и ответа, строгость к самому себе. Он сознательно отказывался от предлагаемых ему вакантных должностей на кафедрах восточной философии, ссылаясь на отсутствие ораторского дара, что, согласно Канетти, вполне соответствует мыслям Конфуция - не угождать никому своим красноречием и не делать карьеру благодаря речам [Канетти, 1990, с. 91]. «Кин думал цитатами и писал хорошо продуманными абзацами» [Канетти, 2000, с. 39]. Для подкрепления своих доказательств Кин использует цитирования из того огромного материала, который хранится в его голове. Его научная память не знает границ, но сосредоточенный на науке, он был не в состоянии заметить того, что происходит вокруг него.

В одном образе Э. Канетти совмещает два и более персонажа из других произведений. В главе «Хитроумный Одиссей» Петер Кин сравнивает себя с Одиссеем, греческим героем, пострадавшим от женщин. Тереза 
для него - это воплощение всех дерзких и коварных женщин в одном образе: мстительной Кримхильды, жестокой Геры, Цирцеи, Калипсо, Навсикаи и других.

Как предостережение звучат слова, цитируемые Кином:

Слишком доверчивым быть, Одиссей, берегися с женою;

Ей открывать простодушно всего, что ть знаешь, не должно [Канетти, 2000, с. 546], подобным образом, следуя своим научным соображениям, раскрывает Петер Кин сложившуюся жизненную ситуацию перед братом Георгом, признавая собственную оплошность. Данная интертекстуальность становится способом выражения пародийности в тексте. Пародия на ученого, с головой ушедшего в свой мир, демонстрирует узость жизненного пространства и неспособность героя ориентироваться в «большом» мире.

Большая роль в романе отводится библейскому интертексту, поскольку в книге затронуты проблемы духовной катастрофы общества, борьба между нравственными ценностями и общественными пороками. Аллюзивный пласт и реминисценции, ориентируемые на библейскую тематику, выявляют характеры действующих фигур и имеют порой комическую направленность. Т. Федяева в комментариях к роману указывает на часто встречающуюся перекодировку христианских символов в произведении, благодаря чему и возникает ироническая игра смыслов [Канетти, 2000, с. 581]. Тереза олицетворяет себя с белым голубем, символом чистоты, невинности и Святого Духа, Петер Кин для неё является Иудой. Посещая церковь, она выбрала самый большой собор в городе, так как меньшая церковь напоминала бы ей о том, что ей причитается больше. Сам же Петер Кин сравнивает себя с Христом и подобно ему читает свои проповеди, но не перед людьми, а перед рядами бесчисленных книг в своей библиотеке.

Царящая в тексте разобщенность между героями вызывает ассоциации с библейским эпизодом о вавилонской башне. Не случайно американский перевод книги 1946 г. вышел под заглавием «The Tower of Babel» («Вавилонская башня»). Скрытые каждый за своей «акустической маской» фигуры общаются между собой, но друг друга не понимают. Проблема коммуникации в современном обществе отображается через конфликт в романе, ставший следствием сосредоточенности героев на собственных интересах и целях и отсутствия восприятия окружающих.

Многие исследователи (D. Barnouw, K.Bartsch, B.Greiner, K. Schutti, E. Шастина) проводят параллель между названием романа и библейской историей «Ослепление Самсона». Подобно библейскому герою Кин становится жертвой слепой любви, в данном случае любви к книгам. Корыстная Тереза олицетворяет собой Далилу. При помощи хитрости и обмана женив на себе Кина, она пытается завладеть его состоянием. Основная мысль ветхозаветной истории идти по пути Бога, не поддаваясь собственным эмоциям, и не давать ненависти выплеснуться в чувство мести. Слепота Самсона является 
символическим отражением слепоты духовной. Забыв о своем предназначении, Самсон идет другим путем. Также как Самсоном Кином, ослепленным ненавистью к Терезе, движет чувство мести, и он создает план по её уничтожению.

Каждый герой романа ослеплен определенной целью, ставшей для него идеей фикс, для достижения которой он готов переступить моральные принципы и нормы. Через образы действующих фигур писатель дает картину общества, погрязшего в море бездуховности и безнравственности.

Й. Эдфельд, член Шведской академии, указывает на наличие в романе фантастических и демонических элементов, что вызывает ассоциации с произведениями таких русских писателей, как Н. Гоголь и Ф. Достоевский [Edfild, 1981, S. 16]. Да и сам Канетти писал, что при создании романа большое влияние на него оказал Гоголь, в образах которого был бросающийся в глаза гротеск. «Это должны были быть фигуры очень экстремальные, доведенные до крайности настолько, насколько это было возможно, комические и ужасные одновременно, при этом ужасное от комического должно быть неотделимо» [Canetti, 1996, S. 38] - пишет Э. Канетти в третьем томе автобиографии. Именно такая характеристика просвечивается в образе горбуна Фишерле: «Тут рядом с ним возник огромный горб и спросил, можно ли присесть. Кин напряженно посмотрел вниз. Где был рот, откуда это донеслось? А обладатель горба, карлик, уже вскочил на стул. Он уселся на нем как следует и обратил к Кину пару больших грустных глаз. Кончик его крючковатого носа уходил в подбородок. Рот у него был так же мал, как он сам, только найти его было невозможно. Ни лба, ни ушей, ни шеи, ни туловища - этот человек состоял из горба, из мощного носа и двух черных, спокойных, печальных глаз» [Канетти, 2000, с. 193]. Стоит заметить, что Канетти сродни Гоголю, создавшему целый ряд типов характеров, ставших нарицательными, создает ряд образов, изложенных в книге «Недреманное ухо. 50 характеров» («Der Ohrenzeuge. 50 Charaktere».). Так в фигуре Терезы легко угадывается канеттиевская Скопидомка - «С деньгами она обходится аккуратно и с нежной заботой, никогда не тратит больше десятой части и печется об остальном» [Канетти, 1990, с. 229].

E.M. Шастина, рассуждая о влиянии Гоголя на манеру письма Канетти, утверждает, что поэтика Гоголя, сочетая в себе фантастическое и обыденное, возвышенное и низменное, имела для Канетти весьма большое значение, как выражение нового отношения к «распавшемуся миру» [Шастина, 2014, с. 194].

Интертекст образует в «Ослеплении» сюжетную ткань. Использование в тексте библейских и мифологических мотивов и образов, прочих литературных традиций - это не только способ выражения действительности, но и особый способ самовыражения поэта, отражение его мифологического мироощущения. 


\section{Литература}

Канетти Э. Из книги: «Недреманное ухо. 50 характеров»: перевод С. Власова // Человек нашего столетия: пер. с нем. / сост. и авт. предисл. Н.С. Павлова; коммент. Р.Г. Каралашвили. М.: Прогресс, 1990. С. 216-249.

Канетти Э. Конфуций в своих «Беседах» / пер. С. Шлапоберской // Человек нашего столетия: пер. с нем./ сост. и авт. предисл. Н.С. Павлова; коммент. Р.Г. Каралашвили. М.: Прогресс, 1990. С. 91-96.

Канетти Э. Ослепление / пер. С. Апта; предисл. Д. Затонского; коммент. Т. Федяевой. СПб: Симпозиум, 2000. 597 с.

Шастина Е.М. Творчество Элиаса Канетти: проблемы поэтики: монография. Казань: Изд-во «ФАН», 2004. 288 с.

Шастина Е.М. Рецепция русской литературы в творчестве Элиаса Канетти // Вестн. Нижегородского ун-та им. Н.И. Лобачевского, 2014. № 2 (3). C. $193-198$.

Canetti E. Das Augenspiel. Lebensgeschichte (1931-1937). Frankfurt am Main: Fischer Taschenbuch Verlag, 1996. 304 S.

Edfild P.J. Verleihungsrede anlässlich der feierlichen Überreichung des Nobelpreises für Literatur an Elias Canetti am 10. Dezember 1981 // Canetti E. Die Blendung. Zürich: Coron Verlag, 1981.657 S.

\section{References}

Edfild P.J. Verleihungsrede anlässlich der feierlichen Überreichung des Nobelpreises für Literatur an Elias Canetti am 10. Dezember 1981. Canetti E. Die Blendung. Zürich, Coron Verlag, 1981, 657 p.

Kanetti E. Iz knigi: «Nedremannoe ukho. 50 kharakterov»: perevod S. Vlasova. Chelovek nashego stoletiya. Per. s nem. sost. i avt. predisl. N.S. Pavlova. komment. R.G. Karalashvili. Moscow: Progress, 1990. pp. 216-249. (In Russian).

Kanetti E. Konfutsii v svoikh «Besedakh». Per. S. Shlapoberskoi. Chelovek nashego stoletiya. Per. s nem. Sost. $i$ avt. predisl. N.S. Pavlova. Komment. R.G. Karalashvili. M.: Progress, 1990. pp. 91-96. (In Russian).

Kanetti E. Osleplenie:Per.S. Apta, Predisl.D.Zatonskogo.Komment.T. Fedyaevoi. $\mathrm{SPb}$.: Simpozium, 2000.597 p. (In Russian).

Shastina E.M. Tvorchestvo Eliasa Kanetti: problemy poetiki. Monografiya. Kazan’: Izd-vo «FAN», 2004. 288 p. (In Russian).

Shastina E.M. Retseptsiya russkoi literatury v tvorchestve Eliasa Kanetti. Vestnik Nizhegorodskogo un-ta im. N.I. Lobachevskogo, 2014, no. 2 (3). pp. 193-198. (In Russian).

Alena G. Barova (Elabuga, Tatarstan, Russian Federation) Intertext Functioning in the Novel by E. Canetti «Blinding»

An attempt is made to study intertext and its functions in the novel «Blinding» by Elias Canetti. It is shown that intertext is one of the techniques for creating a grotesque and parody in a work. Including various literary traditions in the text, the writer expresses the attitude to the prevailing reality and draws a picture of society in connection with the vision of the world.

Key words: intertext, citation, allusion, literary tradition.

Alena G. Barova - senior lecturer of German philology dpt. Elabuga institute of Kazan Federal University. Elabuga, Tatarstan, Russian Federation. Phone:::8-987-219-3718, e-mail: AGBarova81@mail.ru 